\title{
Persepsi Siswa Terhadap Kinerja Guru Bimbingan dan konseling yang Bersertifikasi Pendidik
}

\author{
Ferry Adji Nugroho \\ SMK Muhammadiyah 1 Imogiri \\ Desa Garjoyo, Imogiri, Bantul, DI Yogyakarta, Indonesia \\ Email: ferryadjinugroho@gmail.com
}

\begin{abstract}
This study aimed to describe the perception of students on teacher performance counseling certified educators (the field of guidance and counseling). the method in this research is descriptive quantitative research. The research was conducted in SMP N 1 Banguntapan, with a population of students of class IX in SMP N 1 Banguntapan with the number of 30 students. Instruments in this study using a questionnaire with data analysis techniques using grouping criteria, moderate, and less. The results obtained in this study concluded that students' perceptions of teacher performance guidance and counseling in both categories on the basis of the data categories of each aspect, among others: aspects of personal competence with the number of 14 students (47\%), aspects of social competence with number 25 students (83\%), and aspects of professional competence by the number of 23 students $(77 \%)$. This study may provide information to teachers BK to improve performance related to personal competence, social, and professional, so it can be a teacher BK capable of carrying out its duties and responsibilities in providing guidance and counseling services in schools optimally.
\end{abstract}

Keywords: perception, performance counseling teacher, educator certification

Penelitian ini bertujuan untuk mendeskripsikan persepsi siswa terhadap kinerja guru bimbingan dan konseling yang bersertifikasi pendidik (bidang bimbingan dan konseling). Metode dalam penelitian ini yaitu penelitian deskriptif kuantitatif. Penelitian ini dilaksanakan di SMP N 1 Banguntapan Bantul, dengan subyek penelitian siswa kelas IX di SMP N 1 Banguntapan dengan jumlah 30 siswa yang diambil dengan menggunakan teknik startafied random sampling. Instrumen dalam penelitian ini menggunakan angket dengan teknik analisis data menggunakan pengelompokkan kriteria baik, sedang, dan kurang. Hasil yang diperoleh dalam penelitian ini disimpulkan bahwa persepsi siswa terhadap kinerja guru bimbingan dan konseling dalam kategori baik dengan berdasarkan data kategori dari masing-masing aspek, antara lain: aspek kompetensi kepribadian dengan jumlah 14 siswa (47 \%), aspek kompetensi sosial dengan jumlah 25 siswa (83 \%), dan aspek kompetensi professional dengan jumlah 23 siswa (77\%). Penelitian ini dapat memberikan informasi kepada guru bimbingan dan konseling untuk dapat meningkatkan kinerja yang berhubungan dengan kompetensi kepribadian, sosial, dan profesional, sehingga dapat menjadi guru bimbingan dan konseling yang mampu melaksanakan tugas dan tanggungjawabnya dalam memberikan layanan bimbingan dan konseling di sekolah secara optimal.

Kata kunci: persepsi, kinerja guru bimbingan dan konseling, sertifikasi pendidik

\section{Pendahuluan}

Profesionalitas seorang guru dalam melaksanakan tugas sebagai pendidik sangat penting. Semakin guru itu bisa menunjukkan kinerja yang baik, maka siswa, sekolah dan segenap warga sekolah akan bisa merasakan kinerja guru tersebut. Oleh karena itu sikap profesional baik tetap dijaga oleh seorang konselor yang memang benar-benar ingin menunjukkan kualitas kinerjanya sebagai seorang konselor professional.

Keberadaan bimbingan dan konseling di sekolah dijadikan tempat untuk membantu memandirikan siswa agar setiap peserta didik mampu berkembang sesuai dengan tugas-tugas perkembangan yang ada. Hakikat bimbingan konseling di sekolah bertujuan untuk dapat mendampingi siswa dalam beberapa hal. Pertama, dalam perkembangan belajar di sekolah. Kedua, mengenal diri sendiri dan mengerti kemungkinankemungkinan yang terbuka bagi siswa, sekarang maupun yang akan datang. Ketiga, menentukan cita-cita dan tujuan dalam hidup, serta menyusun rencana yang tepat untuk mencapai tujuan-tujuan itu. Keempat, mengatasi masalah pribadi yang mengganggu belajar di sekolah. Empat peran di atas dapat efektif, jika guru Bimbingan dan konseling Mampu Melaksanakan layanan dengan baik. 
Pada dunia pendidikan, peran guru bimbingan dan konseling sangatlah penting dimulai dari pendidikan sekolah dasar sampai pendidikan di perguruan tinggi. Biasanya peran guru bimbingan dan konseling akan mulai diuji ketika guru sudah terjun di sekolah. Meski sudah ada beberapa program bimbingan dan konseling di sekolah dasar, namun peran guru bimbingan dan konseling biasanya dimulai dari pendidikan sekolah menengah atau SMP yang memang kebanyakan sudah terdapat program bimbingan dan konseling di sekolah. Dimulai dari sekolah menengah tersebut, guru bimbingan dan konseling akan mulai menunjukkan kinerja dalam memberikan layanan bimbingan dan konseling. Oleh karena itu, dalam penelitian ini peneliti berusaha menggali kinerja guru bimbingan dan konseling di SMP lewat persepsi dari siswa dan siswi di sekolah.

Terlepas dari terjunnya guru bimbingan dan konseling di SMP, kinerja ideal seorang guru atau konselor profesional dipersyaratkan memiliki kualifikasi akademik yang relevan dengan mata pelajaran yang diampunya dan menguasai kompetensi sebagaimana dituntut oleh Undangundang Guru dan Dosen. Pengakuan guru sebagai pendidik profesional dibuktikan melalui sertifikat pendidik yang diperoleh melalui suatu proses yang disebut sertifikasi. Sertifikasi bagi guru dalam jabatan sebagai salah satu upaya peningkatan mutu guru diharapkan dapat meningkatkan mutu pendidikan pada satuan pendidikan formal. Untuk itu, terus dilakukan perbaikan pelaksanaan sertifikasi guru.

Berdasarkan uraian di atas tentu sudah menjadi tugas seorang guru bimbingan dan konseling yang memiliki tunjangan sertifikasi benar-benar menunjukkan kualitas sebagai konselor. Baik itu dalam membuat program layanan sampai melaksanakan program layanan bimbingan dan konseling tersebut. Namun pada kenyataan, sebagian dari guru bimbingan dan konseling yang telah sertifikasi belum dapat menunjukkan kinerja secara maksimal.

Problematika tentang kinerja guru bimbingan dan konseling yang sudah bersertifikasi tentu juga memunculkan berbagai persepsi mengenai peran guru bimbingan dan konseling dalam memberikan layanan, entah itu persepsi yang baik maupun persepsi buruk terhadap kinerja guru bimbingan dan konseling. Seperti realita di lapangan pada hasil penelitian yang dilakukan oleh Sisrianti, dkk (2013:34) mengenai persepsi siswa tentang kompetensi kepribadian guru bimbingan dan konseling/Konselor berkenaan dengan aspek menampilkan kinerja berkualitas tinggi, sebanyak $45,07 \%$ siswa menyatakan guru bimbingan dan konseling/konselor selalu menampilkan kinerja berkualitas tinggi, $32,39 \%$ siswa menyatakan guru bimbingan dan konseling/konselor sering menampilkan kinerja berkualitas tinggi, 21,13\% siswa yang menyatakan kadang-kadang dan $1,41 \%$ siswa yang menyatakan guru bimbingan dan konseling/konselor tidak pernah menampilkan kinerja berkualitas tinggi.

Selain relita di atas, berdasarkan pengamatan dan observasi lapangan di beberapa SMP Negeri di Bantul kepada 8 orang guru bimbingan dan konseling pada tanggal 20-22 Mei 2012. Diperoleh informasi mengenai peran konselor di sekolah dalam pemberian pelayanan bimbingan dan konseling sering dianggap sekedar sebagai polisi sekolah. Guru Bimbingan dan konseling yang memiliki tugas dan tanggungjawab dalam terkait tugas dan perkembangan siswa, ditempatkan dalam konteks tindakan-tindakan yang menyangkut disipliner siswa. Memanggil, memarahi, menghukum adalah proses klasik yang menjadi label guru bimbingan dan konseling di banyak sekolah, dengan kata lain, guru bimbingan dan konseling diposisikan sebagai musuh bagi siswa bermasalah atau nakal. Dapat dicontohkan beberapa aspek lain yang perlu dievaluasi dari guru bimbingan dan konseling di SMA Negeri 3 Klaten berdasarkan observasi terhadap guru bimbingan dan konseling di SMA tersebut pada pada tanggal 20 Mei 2012, yaitu belum diterapkannya layanan klasikal di sekolah, belum menggunakan instrument baru (DCM, ITP) dan penyusunan program bimbingan dan konseling yang belum menggunakan model komprehensif. Selain itu beberapa siswa berpendapat bahwa guru bimbingan dan konseling di SMA N 3 Klaten belum mampu memberikan suatu pelayanan yang menarik terhadap siswa sehingga jarang sekali siswa yang mau datang sendiri untuk konsultasi ke ruang bimbingan dan konseling.

Fenomena yang menjadi PR bagi para konselor maupun calon konselor untuk meningkatkan kinerja dalam pelayanan bimbingan dan konseling, terutama pelayanan di sekolah. Apalagi kinerja yang kurang baik 


\section{PERSEPSI SISWA}

ditunjukkan oleh guru bimbingan dan konseling yang sudah menerima tunjangan sertifikasi, yang diharapkan bisa menujukkan contoh yang baik.

Penelitian bertujuan untuk mengetahui gambaran persepsi siswa tentang kinerja guru bimbingan dan konseling yang bersertifikasi pendidik (bidang bimbingan dan konseling) di SMP N 1 Banguntapan. Penelitian ini dapat memberikan informasi kepada guru bimbingan dan konseling untuk dapat meningkatkan kinerja yang berhubungan dengan kompetensi kepribadian, sosial, dan profesional, sehingga dapat menjadi guru bimbingan dan konseling yang mampu melaksanakan tugas dan tanggungjawabnya dalam memberikan layanan bimbingan dan konseling di sekolah secara optimal.

\section{Kajian Literatur}

\section{Persepsi}

Menurut Walgito (2010: 99) mengartikan persepsi adalah suatu proses penginderaan, yaitu proses penerimaan stimulus oleh individu melalui alat indera atau juga disebut proses sensoris. Namun proses itu tidak berhenti begitu saja, melainkan stimulus tersebut diteruskan dan proses selanjutnya merupakan proses persepsi. Karena itu proses persepsi tidak dapat lepas dari proses penginderaan, dan proses penginderaan merupakan proses pendahulu dari proses persepsi.

Persepsi kadang berbeda satu orang dengan yang lain meskipun hal yang ditanggapi sama, sehingga kadang persepsi yang diterima seseorang tidak sesuai dengan apa yang sebenarnya terjadi. Hal tersebut dapat disebabkan oleh situasi batin seseorang, kemampuan analisa, serta kurang sempurna keterangan yang ditangkap. Oleh itu sangat mungkin terjadi perbedaan persepsi siswa tentang kinerja guru bimbingan dan konseling yang sudah bersertifikasi.

Sejalan dengan hal tersebut Mu'arifah (2010:34) menjelaskan pengertian persepsi adalah proses yang mengorganisir dan menggabungkan data indera, sehingga dapat menyadari disekeliling kita. Menurut Woodworth dan Marquis dalam Walgito (2005: 99-100), proses penginderaan akan berlangsung setiap saat, pada waktu individu menerima stimulus melalui alat indera, yaitu melalui mata sebagai penglihatan, telinga sebagai alat pendengar, hidung sebagai alat pembauan, lidah sebagai alat pengecapan, kulit pada telapak tangan sebagai alat perabaan; yang kesemuanya merupakan alat indera yang digunakan untuk menerima stimulus dari luar individu. Alat indera tersebut merupakan alat penghubung antara individu dengan dunia luarnya. Stimulus yang di indera itu kemudian oleh individu diorganisasikan dan diinterpretasikan, sehingga individu menyadari, mengerti tentang apa yang diindera itu dan proses ini disebut persepsi.

Berdasarkan beberapa pengertian yang telah diuraikan di atas bahwa persepsi merupakan suatu proses hubungan manusia dengan lingkungan yang melibatkan tahapan-tahapan yang saling terintegrasi satu sama lain, yaitu berupa proses menangkap stimulus (rangsang), kognitif dan dan upaya menginterpretasikan stimulus. Sehingga penelitian ini diharapkan dapat memberikan masukan positif agar siswa memiliki gambaran atau penilaian tentang kinerja guru Bimbingan dan konseling yang sudah bersertifkasi.

Walgito (2010:101) memaprkan beberapa faktor yang berperan dalam persepsi, antara lain:

\section{Objek yang dipersepsi}

Objek menimbulkan stimulus yang mengenai alat indera atau reseptor. Stimulus dapat datang dari luar individu yang mempersepsi, tetapi juga dapat datang dari dalam diri individu yang bersangkutan yang langsung mengenai syaraf penerima yang bekerja sebagai reseptor. Namun sebagian terbesar stimulus datang dari luar individu.

2. Alat Indera, Syaraf, dan Pusat Susunan Syaraf

Alat indera atau reseptor merupakan alat untuk menerima stimulus. Disamping itu juga harus ada syaraf sensoris sebagai alat untuk meneruskan stimulus yang diterima reseptor ke pusat susunan syaraf, yaitu otak sebagai pusat kesadaran. Sebagai alat untuk mengadakan respon diperlukan syaraf motoris.

\section{Perhatian}

Untuk menyadari atau mengadakan persepsi diperlukan adanya perhatian, yaitu merupakan langkah pertama sebagai suatu persiapan dalam rangka mengadakan persepsi. Perhatian merupakan pemusatan atau konsentrasi dari seluruh aktifitas individu 
yang ditujukan kepada sesuatu atau sekumpulan objek.

Menurut Mu'arifah (2010: 38) persepsi merupakan suatu interaksi rumit yang melibatkan paling tidak tiga komponen utama, yaitu: seleksi, penyusunan, dan penafsiran. Adapun penjelasan dari kutipan diatas adalah sebagai berikut:

1. Seleksi merupakan proses penyaringan oleh indera terhadap stimulus. Dalam proses ini, struktur kognitif yang telah ada akan menyeleksi, membedakan data yang masuk dan memilih data mana yang relevan sesuai dengan kepentingan dirinya. Jadi selektif perseptual ini tidak hanya tergantung pada determinan-determinan utama dari perhatian, seperti intensitas, kualitas, kesegaran, kebaruan, gerakan, dan kesesuai, dengan muatan kesadaran yang telah ada melainkan juga bergantung pada minat, kebutuhankebutuhan, dan nilai-nilai yang dianut.

2. Penyusunan adalah proses mereduksi, mengorganisasikan, menyederhanakan informasi yang kompleks kedalam suatu pola yang bermakna”. Sesuai dengan teori Gestalt, manusia secara alamiah memiliki kecenderungan tertentu dan melakukan penyederhanaan struktur di dalam mengoganisasikan objek-objek perseptual. Maka Gestalt mengajukan beberapa prinsip tentang kecenderungan kecenderungan manusia dalam menyusun informasi ini, diantaranya prinsip kemiripan (similarity), prinsip kedekatan (proximity), prinsip ketertutupan atau kelengkapan (closure), prinsip searah (direction), dll.

3. Penafsiran merupakan proses menginterpretasikan informasi atau stimulus ke dalam bentuk tingkah laku sebagai respon". Dalam proses ini individu membangun kaitan-kaitan antara stimulus yang datang dengan struktur kognitif yang lama, dan membedakan stimulus yang datang untuk memberi makna berdasarkan hasil interpretasi yang dikaitkan dengan pengalaman sebelumnya, dan kemudian bertindak atau bereaksi.

Secara umum proses persepsi siswa terhadap kinerja guru Bimbingan dan konseling adalah pada proses pemberian layanan bimbingan kepada siswa. Menurut Prayitno (2004: 254) ada tujuh jenis layanan bimbingan dan konseling, yaitu:
1. Layanan orientasi, merupakan layanan yang dilakukan untuk memperkenalkan siswa baru dan atau seseorang terhadap lingkungan yang dimasuki.

2. Layanan informasi, merupakan layanan pemahaman yang diberikan untuk menentukan tujuan yang dikehendaki.

3. Layanan penempatan dan penyaluran, merupakan layanan penempatan dan penyaluran adalah layanan yang diberikan kepada individu untuk dapat menyalurkan bakat dan minat yang sesuai dengan kondisi diri individu.

4. Layanan bimbingan belajar (pembelajaran) merupakan layanan yang diberikan kepada individu yang mengalami kegalan atau kesulitan dalam belajar atau yang layanan yang diberikan kepada individu untuk dapat mengembangkan kebiasan belajar yang baik.

5. Layanan konseling perorangan merupakan layanan khusus antara konselor dengan konseli secara tatap muka dengan tujuan mengentaskan masalah konseli.

6. Layanan bimbingan kelompok merupakan layanan bimbingan yang diberikan dalam suasana kelompok untuk membantu menyusun rencana dan keputusan yang tepat.

7. Layanan konseling kelompok merupakan layanan yang diberikan kepada peserta didik untuk membahas dan mengentaskan permasalahan yang dialaminya melalui dinamika kelompok.

Bedasarkan layanan bimbingan yang sering dilaksanakan oleh guru bimbingan dan konseling tersebut maka secara umum siswa juga akan memberikan proses persepsi terhadap pemberian layanan-layanan bimbingan tersebut. Berkaitan dengan kinerja guru bimbingan dan konseling dalam proses pemberian layanan tersebut sudah terangkum dalam UU No. 14 Tahun 2005 tentang Guru dan Dosen pasal 10 tentang kompetensi konselor, yaitu:

\section{Kompetensi Akademik (Pedagogik) Konselor}

Kualifikasi akademik konselor dalam satuan pendidikan pada jalur pendidikan formal dan nonformal adalah sarjana pendidikan (S-1) dalam bidang bimbingan dan konseling dan berpendidikan profesi konselor. Kompetensi pedagogik (akademik) seorang konselor mencakup kemampuan menguasai teori dan praksis pendidikan. mengaplikasikan 
perkembangan fisiologis dan psikologis serta perilaku konseli, menguasai esensi pelayanan bimbingan dan konseling dalam jalur, jenis, dan jenjang satuan pendidikan.

\section{Kompetensi Kepribadian}

Kompetensi kepribadian seorang konselor mencakup kemampuan beriman dan bertakwa kepada Tuhan Yang Maha Esa, menghargai dan menjunjung tinggi nilai-nilai kemanusiaan, individualitas, dan kebebasan memilih, menunjukkan integritas dan stabilitas kepribadian yang kuat, dan menampilkan kinerja berkualitas tinggi.

\section{Kompetensi Sosial}

Kompetensi sosial seorang konselor mencakup kemampuan mengimplementasikan kolaborasi intern di tempat kerja, berperan dalam organisasi dan kegiatan profesi bimbingan dan konseling dan mengimpelementasikan kolaborasi antar profesi.

\section{Kompetensi Profesional}

Kompetensi profesional seorang konselor mencakup kemampuan menguasai konsep dan praksis asesmen untuk memahami kondisi, kebutuhan, dan masalah konseli, menguasai kerangka teoritik dan praksis bimbingan dan konseling, merancang program bimbingan dan konseling, mengimplementasikan program bimbingan dan konseling yang komprehensif, menilai proses dan hasil kegiatan bimbingan dan konseling, memiliki kesadaran dan komitmen terhadap etika profesinal, menguasai konsep dan praksis penelitian dalam bimbingan dan konseling

Tinjauan tentang Guru Bimbingan dan konseling

Permendikbud 81a (2013: lampiran IV) menjelaskan guru bimbingan dan konseling adalah "tenaga yang disiapkan untuk memfasilitasi satuan pendidikan dalam mewujudkan proses pendidikan yang memperhatikan dan menjawab ragam kemampuan, kebutuhan, dan minat sesuai dengan karakteristik peserta didik."

Pendapat lain mengenai pengertian guru bimbingan dan konseling atau konselor dijelaskan dalam Peraturan Pemerintah Nomor 27 Tahun 2008 tentang Standar Kualifikasi Akademik dan Kompetensi Konselor menyatakan bahwa:

Konselor adalah tenaga pendidik professional yang telah menyelesaikan pendidikan akademik strata satu (S-1) program studi bimbingan dan konseling dan program pendidikan profesi konselor dari perguruan tinggi penyelenggara program pengadaan tenaga kependidikan yang terakreditasi.

Berdasarkan uraian di atas dapat disimpulkan bahwa guru bimbingan dan konseling atau konselor adalah tenaga pendidik profesional yang telah menyelesaikan pendidikan akademik strata satu (S-1) program studi bimbingan dan konseling dan program pendidikan profesi konselor yang mempunyai tugas, tanggung jawab, wewenang, dan hak secara penuh dalam kegiatan bimbingan dan konseling terhadap sejumlah peserta didik.

Menjadi seorang guru bimbingan dan konseling harus memenuhi beberapa persyaratan. Hal ini dilakukan agar guru bimbingan dan konseling dapat menjalankan pekerjaan dengan baik Syarat-syarat tersebut dapat di kemukakan sebagai berikut:

Syarat yang berkenaan dengan kepribadian

Seorang guru bimbingan dan konseling harus memiliki kepribadian yang baik. Pelayanan bimbingan dan konseling berkaitan dengan pembentukan perilaku dan kepribadian konseli. Melalui konseling diharapkan terbentuk perilaku positif (akhlak baik) dan kepribadian yang baik pula pada diri konseli.

Syarat yang berkenaan dengan pendidikan

Pelayanan bimbingan dan konseling merupakan pekerjaan profesional. Setiap pekerjaan profesional menuntut persyaratanpersyaratan tertentu antara lain pendidikan. Seorang guru bimbingan dan konseling selayaknya memiliki pendidikan profesi, yaitu jurusan bimbingan konseling Strata Satu (S1), S2 maupun S3. Atau pernah mengikuti pendidikan dan pelatihan tentang bimbingan dan konseling. Syarat yang berkenaan dengan Pengalaman

Pengalaman memberikan pelayanan bimbingan dan konseling berkontribusi terhadap keluasan wawasan pembimbing atau konselor yang bersangkutan. Syarat pengalaman bagi calon guru bimbingan dan konseling paling tidak pernah diperoleh melalui praktik mikro konseling dan praktek Pengalaman Lapangan (PPL) dan pernah memberikan pelayanan bimbingan dan konseling kepada siswa. Pengalaman yang telah dihayati dalam kehidupan, akan membantu mendiagnosis dan mencarikan alternatif solusi terhadap masalah klien. 


\section{Syarat yang berkenaan dengan Kemampuan}

Konselor tidak akan dapat melaksanakan tugas secara baik jika tidak memiliki kemampuan dan keterampilan, maka konselor dituntut untuk memiliki berbagai keterampilan melaksankan konseling. guru bimbingan dan konseling harus mampu mengetahui dan memahami secara mencalam sifat-sifat seseorang, daya kekuatan pada diri seseorang, dan mendiagnosis berbagai persoalan siswa, serta mengembangkan potensi individu secara positif.

Pendapat lain mengenai syarat-syarat guru bimbingan dan konseling dikemukakan oleh Walgito (2010: 40), yang menyatakan bahwa ada beberapa syarat menjadi seorang guru bimbingan dan konseling, adapun syarat tersebut antara lain:

1. Seorang guru bimbingan dan konseling harus mempunyai pengetahuan yang cukup luas, baik segi teori maupun praktik. Segi teori merupakan hal yang penting karena segi inilah yang menjadi landasan di dalam praktik. Segi praktik sangat perlu dan penting, karena bimbingan dan konseling merupakan applied science, ilmu yang harus diterapkan dalam praktik sehari-hari.

2. Seorang guru bimbingan dan konseling hendak memiliki kemantapan atau kestabilan di dalam psikis, terutama dalam segi emosi.

3. Seorang guru bimbingan dan konseling harus sehat jasmani maupun psikis.

4. Seorang guru bimbingan dan konseling harus mempunyai kecintaan terhadap pekerjaa dan juga terhadap anak atau individu yang dihadapi.

5. Seorang pembimbing harus mempunyai inisiatif yang baik sehingga diharapkan usaha bimbingan dan konseling dapat berkembang ke arah yang lebih baik.

6. Seorang guru bimbingan dan konseling harus bersikap supel, ramah tamah, sopan santun di dalam segala perbuatannya. Sehingga guru bimbingan dan konseling dapat bekerja sama dan memberikan bantuan untuk kepentingan anak-anak.

7. Seorang guru bimbingan dan konseling diharapkan mempunyai sifat-sifat yang dapat menjalankan prinsip-prinsip serta kode etik bimbingan dan konseling dengan baik.

Kualitas pribadi guru bimbingan dan konseling atau konselor dijelaskan oleh Cavanagh dalam Yusuf dan Juntika (2010: 37) kualitas pribadi guru bimbingan dan konseling atau konselor ditandai dengan beberapa karakteristik yaitu: pemahaman diri, kompeten, memiliki kesehatan psikologis yang baik, dapat dipercaya, jujur, kuat, responsif, hangat, sabar, sensitive, dan mmiliki kesadaran yang holistic.

Menurut Salahudin (2010:193) kualitas pribadi guru bimbingan dan konseling adalah "kriteria yang menyangkut segala aspek kepribadian yang amat penting dan menentukan keefektifan guru bimbingan dan konseling." Kualitas guru bimbingan dan konseling adalah semua kriteria unggulan termasuk pribadi, pengetahuan, wawasan, keterampilan, dan nilainilai yang dimiliki yang akan memudahkan dalam menjalankan proses konseling sehingga mencapai tujuan dengan berhasil (efektif).

Pendapat lain mengenai kualitas pribadi guru bimbingan dan konseling atau konselor dijelaskan oleh Cavanagh dalam Yusuf dan Juntika (2010: 37) kualitas pribadi guru bimbingan dan konseling atau konselor ditandai dengan beberapa karakteristik sebagai berikut:

1. Pemahaman diri atau self-knowledge berarti bahwa konselor memahami dirinya dengan baik, dia memahami secara pasti apa yang dia lakukan, mengapa dia melakukan hal itu, dan masalah apa yang harus dia selesaikan. Pemahaman diri sangat penting bagi konselor. Oleh karena itu konselor dituntut bisa memahami diri sendiri dengan baik sebelum memberikan layanan bimbingan dan konseling kepada konseli.

2. Kompeten, yang berarti konselor memiliki kualitas fisik, intelektual, emosional, sosial, dan moral sebagai pribadi yang berguna. Satu hal penting yang membedakan hubungan persahabatan dengan hubungan konseling adalah kompetensi yang dimiliki konselor. Konselor yang efektif adalah yang memiliki (a) pengetahuan akademik, (b) kualitas pribadi, dan (c) keterampilan konseling.

3. Memiliki kesehatan psikologis yang baik. Konselor dituntut untuk memiliki kesehatan psikologis yang lebih baik dari konseli. Kesehatan psikologis konselor yang baik sangat berguna bagi hubungan konseling. Aapabila konselor kurang sehat dalam hal psikis, maka dia akan teracuni atau terkontaminasi oleh kebutuhan sendiri, 


\section{PERSEPSI SISWA}

persepsi yang subjektif, nilai-nilai yang keliru, dan kebingungan.

4. Dapat dipercaya yang berarti bahwa konselor tidak menjadi ancaman atau penyebab kecemasan bagi konseli. Kualitas konselor yang dapat dipercaya sangat penting dalam konseling, karena esensi tujuan konseling adalah mendorong konseli untuk mengemukakan masalah individu yang paling dalam.

5. Jujur yaitu konselor bersikap transparan (terbuka), autentik, dan asli (genuine). Sikap jujur penting dalam konseling, karena sikap keterbukaan memungkinkan konselor dan konseli untuk menjalin hubungan psikologis yang lebih dekat satu sama lainnya di dalam proses konseling.

6. Kuat, sebab dengan hal itu konseli akan merasa aman. Konseli memandang konselor sebagai orang yang tabah dalam menghadapi masalah, dapat mendorong konseli untuk mengatasi masalah, dan dapat menanggulangi kebutuhan dan masalah pribadi.

7. Responsif merupakan Keterlibatan konselor dalam proses konseling bersifat dinamis, tidak pasif. Melalui respon yang aktif, konselor dapat mengkomunikasikan perhatian dirinya terhadap kebutuhan konseli.

8. Bersikap hangat yang dimaksud adalah ramah, penuh perhatian, dan memberikan kasih sayang.

9. Melalui kesabaran konselor dalam proses konseling dapat membantu konseli untuk mengembangkan dirinya secara alami.

10. Sensitif yang berarti bahwa konselor menyadari tentang dinamika psikologis yang tersembunyi atau sifat-sifat mudah tersinggung, baik pada diri konseli maupun dirinya sendiri. Konselor yang sensitif akan mampu mengungkap atau menganalisis apa masalah yang dihadapi konseli.

11. Pendekatan holistik dalam konseling berarti konselor memahami konseli secara utuh dan tidak mendekatinya secara serpihan. Namun begitu bukan berarti bahwa konselor sebagai seorang ahli dalam segala hal, disini menunjukkan bahwa konselor perlu memahami adanya berbagai dimensi yang menimbulkan masalah klien, dan memahami bagaimana dimensi yang satu memberi pengaruh terhadap dimensi yang lain. Dimensi-dimensi itu meliputi : fisik, intelektual, emosi, sosial, seksual, dan moralspiritual.

\section{Sertifikasi Guru}

Menurut Muchlas (2010:7) "sertifikasi adalah pemberian sertifikat pendidik yang merupakan bukti formal sebagai pengakuan yang diberikan kepada guru dan dosen sebagai tenaga profesional." Kemudian dijelaskan lebih lanjut oleh Depdiknas (2008:289) pada Penetapan Rambu-Rambu Penyelenggaraan Sertifikasi Konselor Dalam Jabatan kaitannya dengan guru yang telah memperoleh sertifikasi adalah sebagai berikut "Pengakuan terhadap seseorang yang telah memiliki kompetensi untuk melaksanakan pelayanan bimbingan dan konseling, setelah yang bersangkutan dinyatakan lulus uji kompetensi yang diselenggarakan oleh lembaga pendidikan tenaga pendidikan (LPTK) program studi Bimbingan dan konseling yang terakreditasi. Kompetensi yang diakses adalah penguasaan kemampuan akademik sebagai landasan keilmuan dari segi penyelenggaraan Iayanan ahli bidang Bimbingan dan konseling".

Permendiknas No. 10 Tahun 2009 tentang sertifikasi guru menyatakan bahwa sertifikasi guru dalam jabatan dilaksanakan melalui uji kompetensi untuk memperoleh sertifikat pendidik. Uji kompetensi tersebut lebih dikenal dengan program sertifikasi guru. Uji kompetensi ini dilakukan untuk memperoleh sertifikat pendidik dan dilakukan dalam bentuk penilaian terhadap kumpulan dokumen yang mencerminkan kompetensi guru. Komponen-komponen portofolio tersebut mencakup kualifikasi akademik, pendidikan dan pelatihan dalam rangka pengembangan dan peningkatan kompetensi, pengalaman mengajar, perencanaan dan pelaksanaan pembelajaran, penilaian dari atasan dan pengawas, prestasi akademik, karya pengembangan profesi, keikutsertaan dalam Forum Ilmiah, pengalaman organisasi di bidang pendidikan dan sosial, dan penghargaan yang relevan dengan bidang pendidikan.

Depdiknas (2008) mengingat ragam yang lebar dalam kompetensi akademik bawaan para pesertanya, dalam Rambu-rambu Penyelenggaraan Program Sertifikasi Konselor Dalam Jabatan ini perlu disediakan menu 
kurikuler pendidikan akademik yang beragam sesuai dengan kebutuhan belajar tiap kelompok peserta program, yaitu (1) Nol SKS untuk lulusan program S1 Bimbingan dan konseling, yang langsung diperkenankan mengikuti Program Sertifikasi Konselor, akan tetapi di pihak lain, secara kurikuler disesuaikan (2) peserta yang merupakan lulusan program Sarjana Muda Bimbingan dan konseling atau lulusan Crash Program, yang terlebih dahulu diwajibkan untuk memenuhi persyaratan untuk meraihijasah sarjana pendidikan dengan kekhususan bidang Bimbingan dan konseling, sedangkan (3) peserta yang merupakan lulusan program S1 Psikologi dipersyaratkan untuk mengikuti program aanvoelen sehingga meraih pemampuan akademik yang setara dengan kemampuan akademik lulusan program S-1 Bimbingan dan konseling. Persyaratan Sertifikasi untuk perolehan Sertifikat Konselor adalah sama untuk semua peserta, setelah mereka dinilai berhasil menguasai dengan baik kompetensi akademik bimbingan dan konseling yang dipersyaratkan sesuai dengan ketentuan perundang-undangan.

\section{Kinerja Guru Bimbingan dan Koseling}

Kata kinerja merupakan terjemahan dari bahasa Inggris, yaitu dari kata performance. Kata performance berasal dari kata to perform yang berarti menampilkan atau melaksanakan. Performance berarti prestasi kerja, pelaksanaan kerja, pencapaian kerja, unjuk kerja atau penampilan kerja. Dalam materi diklat Penilaian Kinerja Guru yang diterbitkan oleh Direktorat Tenaga Kependidikan (2008: 20), "kinerja merupakan suatu wujud perilaku seseorang atau organisasi dengan orientasi prestasi”.

Pendapat para ahli mengenai pengertian kinerja cukup beragam. Menurut Barnawi dan Arifin (2012: 13) kinerja adalah "tingkat keberhasilan seseorang atau kelompok dalam melaksanakan tugas sesuai dengan tanggung jawab dan wewenangnya berdasarkan standar kinerja yang telah ditetapkan selama periode tertentu dalam rangka mencapai tujuan." Tingkat keberhasilan seseorang atau kelompok orang dalam melaksanakan tugas dan tanggung jawabnya serta kemampuan untuk mencapai tujuan dan standar yang telah ditetapkan."
Berdasarkan beberapa pendapat diatas, dapat disimpulkan bahwa kinerja adalah prestasi kerja, pencapaian kerja, atau unjuk kerja seseorang dalam melaksanakan tugas sesuai dengan tanggung jawab dan wewenang berdasarkan standar kinerja yang telah ditetapkan selama periode tertentu.

Adapun standar kompetensi guru bimbingan dan konseling dijelaskan dalam Peraturan Pemerintah Nomor 27 Tahun 2008 tentang Standar Kualifikasi Akademik dan Kompetensi Konselor. Pendapat mengenai sosok utuh kompetensi profesional konselor dijelaskan pula oleh Kartadinata (2008: 142), yaitu memahami secara mendalam konseli yang hendak dilayani, menguasai landasan teoritik bimbingan dan konseling, menyelenggarakan bimbingan dan konseling yang memandirikan, dan mengembangkan pribadi dan profesionalitas secara berkelanjutan. Kinerja guru bimbingan dan konseling dipengaruhi oleh beberapa faktor. Faktor tersebut bisa berasal dari dalam diri (internal) dan faktor yang bersal dari luar (eksternal). Kedua faktor tersebut membawa dampak terhadap kinerja guru bimbingan dan konseling. Menurut Gibson (Suyatminah, 2013) ada 3 faktor yang berpengaruh terhadap kinerja, pertama faktor individu: kemampuan, ketrampilan, atar belakang keluarga, pengalaman kerja, tingkat sosial dan demografi seseorang. Kedua faktor psikologis: persepsi, peran, sikap, kepribadian, motivasi dan kepuasan kerja. Ketiga faktor organisasi: struktur organisasi, desain pekerjaan, kepemimpinan, dan sistem penghargaan (reward system). Dari berbagai faktor-faktor yang mempengaruhi kinerja guru tersebut, dapat disimpulkan bahwa faktor yang mempengaruhi kinerja guru antara lain faktor internal dan ekterna, faktor secara individu dan kelompok.

\section{Metode Penelitian}

Penelitian ini merupakan jenis penelitian kuantitatif dengan metode deskriptif. Dalam penelitian ini telah ditetapkan pendeskripsian data yang akan diperoleh tanpa mengadakan suatu perlakuan dan treatment tertentu. Penelitian ini dilaksanakan di SMP Negeri 1 Banguntapan yang beralamat di Jalan Karangturi Banguntapan Bantul. 
PERSEPSI SISWA

Subjek dalam penelitian ini adalah siswa kelas IX di SMP N 1 Banguntapan dengan jumlah 30 siswa. Untuk menyetarakan hak siswa menjadi subyek penelitian, maka peneliti menggunakan teknik Startafied Random Sampling yaitu peneliti mengambil perwakilan siswa dari semua kelas sampai memenuhi jumlah 30 siswa secara acak. Pada penelitian ini metode yang dipakai dalam pengumpulan data adalah teknik non tes dengan menggunakan intrumen yang berupa angket. Teknik analisis data yang digunakan dalam penelitian ini menggunakan pengelompokkan kriteria kurang, sedang, dan baik.

\section{Hasil Penelitian Dan Pembahasan}

Analisis data yang dilakuakan peneliti adalah berdasarkan data yang diperoleh dari penelitian lewat pengisian angket persepsis siswa terhadap kinerja guru Bimbingan dan konseling yang bersertifikasi. Angket tersebut memliliki jumlah item sebanyak 40 pernyataan dengan kriteria skor 1-4. Skor 4 adalah skor maksimal dari persepsi siswa terhadap kinerja guru Bimbingan dan konseling, baik dari aspek kompetensi kepribadian, kompetensi sosial, dan kompetensi profesional. Sedangkan skor 1 adalah skor minimal dari persepsi siswa terhadap kinerja guru Bimbingan dan konseling, baik dari aspek kompetensi kepribadian, kompetensi sosial, dan kompetensi profesional. Distribusi kategorisasi dapat dilihat pada Tabel 1

Tabel 1

Distribusi Kategorisasi dan Frekuensi Aspek Kompetensi Kepribadian

\begin{tabular}{lllll}
\hline No & $\begin{array}{c}\text { Interval } \\
\text { Skor }\end{array}$ & Frekuensi & F \% & Kriteria \\
\hline 1 & 46 s.d 60 & 14 & $47 \%$ & Baik \\
2 & 31 s.d 45 & 13 & $43 \%$ & Sedang \\
3 & 15 s.d 30 & 3 & $10 \%$ & Kurang \\
& Total & 30 & $100 \%$ & - \\
\hline
\end{tabular}

Dilihat dari tabel 1 tersebut disimpulkan bahwa dari aspek kompetensi kepribadian berdasar pada tiga kriteria, yaitu baik, sedang, dan kurang. Diperoleh hasil bahwa aspek kompetensi kepribadian cenderung berada pada kategori baik. Selanjutnya untuk mengetahui frekuensi aspek kompetensi sosial dapat dilihat pada Tabel 2.
Tabel 2

Distribusi Kategorisasi dan Frekuensi Aspek Kompetensi Sosial

\begin{tabular}{cclll}
\hline No & $\begin{array}{c}\text { Interval } \\
\text { Skor }\end{array}$ & Frekuensi & F \% & Kriteria \\
\hline 1 & 37 s.d 48 & 25 & $83 \%$ & Baik \\
2 & 25 s.d 36 & 5 & $17 \%$ & Sedang \\
3 & 12 s.d 24 & - & - & Kurang \\
& Total & 30 & $100 \%$ & - \\
\hline
\end{tabular}

Dilihat dari tabel 2 tersebut disimpulkan bahwa dari aspek kompetensi sosial berdasar pada tiga kriteria, yaitu baik, sedang, dan kurang. Diperoleh hasil bahwa aspek kompetensi sosial cenderung berada pada kategori baik. Selanjutnya untuk mengetahui frekuensi aspek kompetensi profesional dapat dilihat pada Tabel 3.

Tabel 3

Distribusi Kategorisasi dan Frekuensi Aspek Kompetensi Profesional

\begin{tabular}{lllll}
\hline No & $\begin{array}{c}\text { Interval } \\
\text { Skor }\end{array}$ & Frekuensi & F \% & Kriteria \\
\hline 1 & 38 s.d 52 & 23 & $77 \%$ & Baik \\
2 & 27 s.d 39 & 7 & $23 \%$ & Sedang \\
3 & 13 s.d 26 & - & - & Kurang \\
& Total & 30 & $100 \%$ & - \\
\hline
\end{tabular}

Dilihat dari tabel 3 tersebut disimpulkan bahwa dari aspek kompetensi profesional berdasar pada tiga kriteria, yaitu baik, sedang, dan kurang. Diperoleh hasil bahwa aspek kompetensi profesional cenderung berada pada kategori baik.

Berdasarkan hasil analisis secara keseluruhan persepsi siswa terhadap kinerja guru Bimbingan dan konseling di SMP N 1 Banguntapan masuk dalam kategori baik. Baik itu dilihat dari aspek kompetensi kepribadian, kompetensi sosial, dan kompetensi profesional. Kategori baik tersebut ditentukan peneliti dengan disesuaikan data skor persepsi sebagai berikut: 14 siswa (47 \%) dari aspek kompetensi kepribadian, 25 siswa (83\%) dari aspek kompetensi sosial, dan 23 siswa (77\%) dari aspek kompetensi professional.

Berdasarkan data hasil penelitian tersebut terdapat beberapa aspek yang dinilai oleh siswa dalam penilaian persepsi terhadap kinerja Guru Bimbingan dan konseling, yaitu: 
1. Kompetensi Kepribadian

a. Beriman dan bertakwa kepada Tuhan Yang Maha Esa.

b. Menghargai dan menjunjung tinggi nilainilai kemanusiaan, individualitas, dan kebebasan memilih.

2. Kompetensi Sosial

a. Memberikan layanan orientasi dan informasi untuk membantu siswa dalam mengenal lingkungan sosial.

b. Memberikan layanan bimbingan pribadi, belajar, sosial, karir.

3. Kompetensi Profesional

a. Mampu melaksanakan layanan BK dan pendukung dalam BK.

b. Mampu melakukan penilaian terhadap layanan yang sudah diberikan kepada siswa.

Melihat dari hasil pembahasan ini, diharapkan guru bimbingan dan konseling di SMP $\mathrm{N} 1$ Banguntapan dapat meningkatkan kinerja dalam pelayanan bimbingan dan konseling, agar nantinya kinerja guru bimbingan dan konseling dapat jauh lebih baik dari persepsi siswa pada penelitian ini.

\section{Simpulan}

Hasil yang diperoleh dari analisis data dan pembahasan, maka dapat disimpulkan bahwa persepsi siswa terhadap kinerja guru Bimbingan dan konseling yang sudah bersertifikasi adalah masuk dalam kategori baik. Ketentuan tersebut dapat didukung dengan keadaan responden yaitu siswa kelas IX di SMP N 1 Banguntapan, yang merupakan siswa yang sudah tiga tahun bersama guru Bimbingan dan konseling dan sudah cukup paham dengan keadaan dan kinerja guru Bimbingan dan konseling mereka. Penelitian ini dapat memberikan informasi kepada guru bimbingan dan konseling untuk dapat meningkatkan kinerja yang berhubungan dengan kompetensi kepribadian, sosial, dan profesional, sehingga dapat menjadi guru bimbingan dan konseling yang mampu melaksanakan tugas dan tanggungjawabnya dalam memberikan layanan bimbingan dan konseling di sekolah secara optimal.

\section{Referensi}

Depdiknas. (2008). Penataan Pendidikan Profesional Konselor dan Layanan Bimbingan dan konseling: dalam Jalur Pendidikan Formal. Jakarta: Departemen Pendidikan Nasional.

Mu'arifah Alif. (2010). Modul Dasar Psikologi. Yogyakarta: Universitas Ahmad Dahlan .

Muchlas Samani, dkk. (2010). Mengenal Sertifikasi Guru di Indonesia. Surabaya: SIC, APPI.

Permendikbud 81a Lampran IV. (2013). Pedoman Umum Pembelajaran. Jakarta

Prayitno, dan Erman Amti. (2004). Dasar-dasar Bimbingan dan konseling. Jakarta: Rineka Cipta.

Salahudin, Anas. (2010). Bimbingan dan konseling. Bandung: Pustaka Setia.

Suyatminah. (2013). Peran Kepemimpinan Transformasional dan Kedisiplinan Kerja Terhadap Kinerja Guru TK PNS seKecamatan Bantul. PSIKOPEDAGOGIA Journal Bimbingan dan Konseling, 2(2): 1824.

Walgito, Bimo. (2010). Bimbingan dan Konseling (Studi dan Karier) Yogyakarta: Penerbit Andi.

Yusuf, Syamsu dan Achmad Juntika Nurihsan. (2010). Landasan Bimbingan dan konseling. Bandung: Remaja Rosdakarya. 